\title{
A New Perspective on the Luxembourgish Genitive ${ }^{1}$
}

\author{
Caroline Döhmer \\ University of Luxembourg
}

\begin{abstract}
This paper deals with genitive constructions in the Luxembourgish language. It is often assumed that the Luxembourgish genitive has only survived in idioms and archaic structures (Russ 1996: 74; Schanen \& Zimmer 2012: 64), but I will investigate this claim in more detail. Based on a qualitative corpus analysis of spoken and written Luxembourgish (over $62 \mathrm{~m}$. tokens), different constructions will be systematically compiled and analyzed. Due to the rising interest in morphosyntactic variation and the improved data situation, this descriptive analysis investigates the current status of the genitive within a single system of grammar, i.e. Luxembourgish. The paper explores six main areas that are relevant for Luxembourgish genitives: attributes, genitive complements of verbs and adjectives, prepositions, adverbials, family names, and partitives. The structures obtained from the corpus will then be discussed from a formal and a functional perspective in order to illustrate Luxembourgish case typology. As the data shows, the genitive behaves differently according to the different areas that have been selected beforehand. On the one hand, genitives can be found in lexicalized structures, i.e. adverbials. On the other hand, different genitives occasionally appear as verb or adjective complements. This phenomenon is partly caused by the expansion of the Luxembourgish language into the written domain. Another main finding is that Luxembourgish makes full use of an independent set of partitive pronouns and determiners that have been derived from former genitives.
\end{abstract}

\section{Introduction}

It has been a standard assumption that the Luxembourgish genitive is archaic and only remains in fossilized structures (Russ 1996: 74; Schanen \& Zimmer 2012: 64). These predictions will be analyzed on the grounds of empirical evidence. The present paper is a descriptive study on the formal and functional properties of the genitive case and its competing constructions in Luxembourgish. The research questions are the following (among others): In which (formal and functional) contexts does the genitive occur? What are the distributional patterns of genitive and other constructions? How does the genitive fit into the case paradigm of this particular language? How can its structural status be assessed (from fossilized to productive)?

The first chapter starts with a brief summary of the Luxembourgish language situation, describing structural characteristics as well as the sociolinguistic status. The

\footnotetext{
${ }^{1}$ I would like to thank Maike Edelhoff for her helpful comments and Robert Durham for improving my English.
} 
main part of the paper explores genitive constructions in six linguistic categories (cf. Willems 1997: 189) ${ }^{2}$ :

- Attributes: Enn des Mounts 'end of the month'

- Genitive complements: enges Sportlers wierdeg 'to be worthy of a sportsman'

- Prepositions: innerhalb Europas 'within Europe'

- Adverbials: enges Daags 'one day'

- Family names: de Schmidts Claude 'Claude Schmidt'

- Partitives: däers Kuch '(some of) the cake'

In this analysis, the research perspective is mainly synchronic in order to outline the actual use of the genitive. The conclusion will summarize the results from a typological point of view and will provide answers to the main research questions.

\section{Characterizing the Luxembourgish language and data}

Before turning to the analysis, some structural and methodological preliminary points need to be established. Luxembourgish (called Lëtzebuergesch ${ }^{3}$ ) is the national language of the Grand-Duchy of Luxembourg. Luxembourgish is a MoselleFranconian dialect that evolved into an Ausbausprache (Kloss 1978). Due to its geographical situation between Germany, France, and (French-speaking) Belgium, and its history of nation building, the country has a trilingual language policy: German, French, and Luxembourgish (cf. Gilles \& Moulin 2003: 303). Although Luxembourgish and German have the same root origin and show structural overlapping, they are considered as two different systems, meaning that there is no continuum between these two languages (no diaglossic system). Lux. is a particularly prestigious language with a high national-symbolic value and is mainly spoken as L1 by the local non-migrant population (cf. Gilles \& Moulin 2003: 305). Since World War II the national language of Luxembourg has undergone different historicalpolitical and sociolinguistic developments: (a) the expansion of a supra-regional variety (dialect leveling), (b) the official language status in 1984, and (c) the enhancement of Luxembourgish in the written domain, effectively triggered by computer-mediated communication (Gilles \& Moulin 2003: 310). These three scenarios have an effect on linguistic use patterns and the ongoing standardization process. This is why it is crucial to carry out qualitative investigations on recent language structure.

\footnotetext{
${ }^{2}$ Willems (1997) describes the system for genitives in the Standard German system. Due to the genealogical relationship between Luxembourgish and German, the extensive research on Standard German and German varieties can be taken as a scientific starting point for this topic.

${ }^{3}$ In the text, I will use the English equivalent Luxembourgish or abbreviated Lux.
} 
The aim of this paper is to provide an empirically adequate picture of use of the genitive in Luxembourgish. The research corpus ${ }^{4}$ contains texts from the years 2003 to 2013. The data consists of the following online and offline text types, displaying different degrees of formality:

- Comments sections on the national news site rtl.lu

- Message boards on the web (on various topics such as cars or photography)

- texts from wikipedia.lu (retrieved 2013)

- Log files from Lux. chatrooms (2003-2006)

- Radio news (text preparation for reading on air)

- Parliamentary reports and political interviews (transcripts)

- Transcripts from family discussions and other interviews

- Term papers from the University of Luxembourg (written in Lux.)

- Luxembourgish literature

The text type will be indicated in brackets next to the example given in the text. Overall, the database contains more than $62 \mathrm{~m}$. tokens. The corpus is not annotated or standardized in any form. All research must be carried out by searching for simple words or regular expressions. All Luxembourgish examples drawn from the corpus are original documents; no corrections have been made at any level (neither stylistic, nor orthographic). Sentences not taken from the corpus are marked with a plus-sign $(+)$.

\section{Preliminary remarks}

Before evaluating the corpus data, some linguistic requirements must be taken into account: (a) authenticity, (b) text type, (c) structural visibility and (d) the notions of productivity, lexicalization, and idiomaticity.

\section{(a) Authenticity}

First, the corpus data needs to contain authentic linguistic material. Authenticity means that the utterances should come from native speakers and reflect the basic use of the language as L1. Due to the anonymity of the Internet data (which represents a major part of the corpus), no speaker profiles (gender, age, nationality, education, etc.) can be compiled. For the non-web-based texts, all authors and/or speakers are native speakers or have a similar linguistic competence. In fact, it is very unusual for non-Luxembourgish people to speak or write Luxembourgish. The authenticity in such a broad corpus can never be fully guaranteed but these data sets nevertheless represent a fruitful source for structural analyses.

\footnotetext{
${ }^{4}$ I want to thank Prof. Peter Gilles for making this broad database available. Special thanks also go to Sophie Neuenkirch for sharing her transcripts with me (family discussions) and a friend of mine, who wishes to remain anonymous, for sending me the chat log files.
} 


\section{(b) Text type}

Some text types enhance new constructions or styles: formal or institutional registers require a repertoire other than everyday language. Chat sessions among teenagers reveal sentences in styles other than poetry or prose. Transcripts of oral speech may contain more constructional flaws than a term paper. Moreover, other factors have been revealed in the research literature. Androutsopoulos (2007: 91) pointed out that in computer-mediated communication (i.e. message boards) the users tend to write differently when they are emotionally charged, e.g. in a heated discussion. For his research on an Internet hip-hop community, he showed that the more a single user was angry (while arguing online), the more elaborate his language structure became. This scenario could also hold for the Luxembourgish data. The Internet data in the corpus comes predominantly from the comments section of the national news site rtl.lu. People mostly use this source to accuse the government or the unfairness of the political system, generally resulting in a sense of victimization. Therefore, the emotional charge in their texts is rather high and may give rise to more elaborate constructions.

Another issue that needs to be addressed is the existence of linguistic repertoires in Luxembourgish. The polyglossia in Luxembourg divides the three central languages (Lux., German, French) into different domains of use (cf. Hoffmann 1996: 103f.; Gilles 2011). As Gilles (2011: 58) points out, very formal text types ('konzeptionell schriftlich') might be taken over by another language, i.e. French for legal texts. The analysis of different diasystems in the Luxembourgish language remains unexplored until today. The scientific fundamentals are therefore not (yet) sufficient to enable precise predictions about styles and registers.

(c) Structural visibility

Case marking in Luxembourgish occurs on the article. The adjective can take inflectional suffixes as well (indicated in morphological brackets). The core case system is shown in the following table. Genitive case marking is deliberately not added, because the corpus study does not provide enough examples of different adjectives within genitive-NPs. I will come back to this point when it comes to the Lux. partitive system in the following chapter. 


\begin{tabular}{|c|c|c|c|}
\hline \multicolumn{4}{|c|}{ Accusative + Nominative $=$ syncretism } \\
\hline M.: & $\{+\mathrm{en}\}$ & den déck-en Hond & 'the big dog' \\
\hline N.: & $\{+\mathrm{t}\}$ & dat déck-t Hong & 'the big chicken' \\
\hline F.: & $\{+\varnothing\}$ & déi déck-ø Kaz & 'the big cat' \\
\hline P1.: & $\{+\varnothing\}$ & déi déck-ø Déier-en & 'the big animals' \\
\hline \multicolumn{4}{|c|}{ Dative } \\
\hline M.: & $\{+\mathrm{em} ;+\mathrm{en}\}$ & d-em déck-en Hond & \\
\hline N.: & $\{+\mathrm{em} ;+\mathrm{en}\}$ & d-em déck-en Hong & \\
\hline F.: & $\{+$ er $\}$ & d-er déck-er Kaz & \\
\hline P1.: & $\{+\mathrm{en}\}$ & d-en déck-en Déier-en & \\
\hline
\end{tabular}

Before turning to the corpus analysis, it is necessary to clarify how genitives can be identified. ${ }^{5}$ On the nominal level, feminine nouns are formally equivalent in the dative and in the genitive. ${ }^{6}$ This is also one reason why predicate genitives have to be left out since they only appear with feminine nouns, such as Meenung ${ }^{\text {FEM }}$ 'opinion' in ech sinn [denger Meenung] ${ }^{\text {DAT=GEN ' } I \text { am in complete agreement with you' or Usiicht }}{ }^{\mathrm{FEM}}$ 'view' in hien ass [eiser Usiicht ${ }^{\mathrm{DAT}=\mathrm{GEN}}$ 'he is sharing our point of view'.

For masculine and neuter NPs, the determiner and sometimes the noun itself are marked with an $\{-\mathrm{s}\}$. The basic, undisputable forms that are taken into consideration are the following: des (definite article), enges/kenges (indefinite article) and senges (possessive article).

Genitives may also appear as regular personal pronouns (ech brauch denger ${ }^{\mathrm{GEN}}$ net 'I don't need you') or in partitive pronouns (ech sinn es ${ }^{\text {PART }} s a t$ 'I am fed up with it'). Some scholars provide paradigms displaying genitive forms of personal pronouns (Russ 1996: 83; Schanen \& Zimmer 2012: 156). The fact that these forms are equivalent to the possessive pronouns and articles (feminine) makes it hard to isolate those genitive forms.

\begin{tabular}{llll}
\hline & \multicolumn{3}{l}{ Personal pronouns (genitive) ${ }^{7}$} \\
\hline 1.pers.sg. & menger & 1.pers.pl. & eiser/onser \\
2.pers.sg. & denger & 2.pers.pl. & ärer \\
3.pers.sg.m. + n. & senger & 3.pers.pl. & hirer \\
3.pers.sg.f. & hirer & & \\
\hline
\end{tabular}

Tab. 2: personal pronouns in the genitive

\footnotetext{
${ }^{5}$ In Luxembourgish, interrogative pronouns do not exist in the genitive, making it hard to clearly identify the constituent structure in the sentence.

${ }^{6}$ The same syncretism holds for Standard German: er gedenkt [seiner Frau ${ }^{\mathrm{GEN}}$ 'he commemorates his wife'; er hilft [seiner Frau $]^{\mathrm{DAT}}$ 'he is helping his wife'. Note that the notion of syncretism refers to the surface structure (strictly formal aspect).

${ }^{7}$ These pronouns can only be used in reference to a person. Partitive pronouns are not mentioned here because they belong to another functional system (see chapter 4).

${ }^{8}$ The forms eiser/onser result from dialect variation but are both considered, General Luxembourgish'.
} 
In this analysis, I will call constructions with overt genitive marking $(\{-\mathrm{s}\}$ for neuter and masculine NPs) 'genitive construction'. Prepositional structures will be called PP (prepositional phrase) with reference to the actual preposition in use. Note that in Luxembourgish, articles may be cliticized onto the preposition (depending on the form and gender of the article).

(d) Productivity, lexicalization, and idiomaticity

Although the term productivity is mostly used in morphology, it can also be applied to (morpho-)syntax. It may be difficult to depict the exact productivity of syntactic patterns, however it should be emphasized if a specific construction remains a single occurrence or if similar constructions can be found in other contexts or with different lexical items. The latter would display a rather high productivity, allowing new instances of the same type.

Even if genitives do occur in the corpus, they may be lexicalized or idiomatized. Terms related to lexicalization and idiomaticity are often used inconsistently or are defined in different ways. In this paper I will stick to the following definitions Lexicalization is a phenomenon that describes the gradual fixation of a word combination into a fixed expression. This fixation or frozenness sometimes goes along with irregular (morpho-syntactic) use patterns or other structural restrictions (Burger 2007: 20f.). Idiomatic constructions are also fixed word combinations, but they are usually opaque in their meaning and based on specific knowledge, e.g. das ist kalter Kaffee 'fig. this is old news' has nothing to do with actual cold coffee, but with old news (cf. Fillmore et al. 1988; Burger 2007: 21f., Szczepaniak 2011: 27).

The main purpose of this study is to identify the 'lively' status of this case, in order to classify the case system from a typological point of view. This is why the corpus study has significant potential.

When it comes to the status of the genitive in Standard German, there is no consensus about the (relic) status of this case. The overall tendency of Standard German is that genitives are gradually regressing (in the basic morphological inventory) and that they are increasingly unproductive (cf. Willems 1997: 189; Ágel 2000: 1870f.; Nübling et al. 2008: 102). However, several studies show that genitives remain stable in certain syntactic contexts, i.e. genitive marking in Standard German still persists in different nominal attributes (cf. Zimmer: this volume) and several prepositions still govern genitive case (cf. Scott 2011, 2014; Szczepaniak 2014). Szczepaniak (2014: 34) even mentions the term of a 'prestige genitive' in Standard German. This corpus study will reveal the status of different genitive constructions in the Luxembourgish language. 


\section{Genitive constructions in Luxembourgish}

- Attributes

Genitival attributes mainly exist on a lexicalized basis. This holds for several time

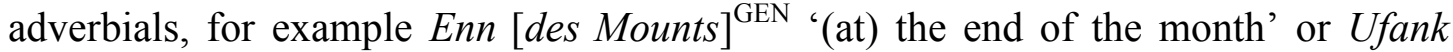

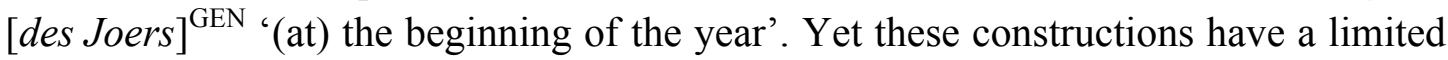
set of nouns with which to operate, namely Mount 'month' and Joer 'year'. This construction is highly fragile, meaning that any NP that bears more information than the two nouns mentioned before is blocked: *Ufank des Schaltjoers '(at) the beginning of the leapyear' or *Ufank nächste Mounts '(at) the beginning of the next month' are not possible. This structural inflexibility marks the lexicalized status of this attributive construction.

Another time indication appearing in the genitive is Zäit senges Liewens 'throughout his life'. The question here is whether this is a true noun+attribute structure or whether (a) this is a lexicalized time expression that can be interpreted as one temporal adverb or (b) the noun Zäit is in this context reanalyzed as a preposition followed by a genitive (this is the case for German, marked by the lower case letter $z$ in zeit seines Lebens). Since it only appears in this structure in the meaning of a temporal adverbial, this construction is rather unproductive and is also idiomatized.

In general, genitive attributes are quite rare. The KWIC-analysis with the possessive article senges ( $3^{\text {rd }}$ pers. singular) and the indefinite article enges (masc./neutr. sing.) shows clear tendencies: The senges $(n=168)$ and enges $(n=659)$ word searches reveal only six genitival attributes, that do not belong to a fixed expression such as Zäit senges Liewens or other syntactic structures.

Although there are only a few instances of 'true' genitive attributes, these structures do occur and should not be ignored. In the following examples the genitive- $s$ does not always appear attached to the noun.

\section{(1) NET CONFORME mat den Normen enges DRENKWASSER not compliant with the.DAT norms a.GEN drink-water ,noncompliant to the norms of drinking water' (rtl.lu comments)}

Some of the encountered genitives prove to be word-for-word translations of German ${ }^{9}$ proverbs: Jidereen as [senges Glecks] ${ }^{\mathrm{GEN}}$ Schmad (rtl.lu comments) ,man forges his own destiny'. An indicator of the structural stability is the archaic preceding genitive attribute, which is unusual both in German and in Luxembourgish.

Other cases in which German patterns have been adapted can be seen in examples (2) and (3). These constructions originate from the Luxembourgish entries on wikipedia.lu. In the field of astronomy, in particular, we see some authors translating

\footnotetext{
${ }^{9}$ The underlying German proverb is the following: Jeder ist seines Glückes Schmied.
} 
the German article into Luxembourgish word for word, resulting in the following sentences:

(2) Sou léisst sech e beschtuschléissendes Ellipsoid (Referenzellipsoid) vun so let itself a best-fitting.? Ellipsoid (reference-ellipsoid) of enger ganzer Regioun oder enges Kontinents ofleeden. a.DAT whole.DAT region or a.GEN continent.GEN deduct 'This way, a best-fitting ellipsoid (referential ellipsoid) can be deducted by a whole region or continent' (wikipedia.lu) ${ }^{10}$

(3) de mëttlere Bunnradius senges Massezentrums the middle track-radius his.GEN mass-centre.GEN ,the track's mid-radius of its mass centre' (wikipedia.lu) ${ }^{11}$

The fact that these authors have applied German syntax patterns on the Luxembourgish language seems fairly obvious (cf. the German neutral suffix \{-es\} on the adjective, which is not available in Lux.). Nonetheless, the morphological inventory of Lux. must also possess those features in order to rebuild these genitive constructions. In other words, if there were no genitive at all, these constructions would never appear. Luxembourgish represents in this case a rather dynamic grammatical system allowing this kind of variation.

Another indication for the word-for-word translations of these users can be seen on the first adjective beschtuschléissendes in (2) that bears an incorrect inflectional suffix: \{-es\} does not exist for Lux. adjectives in the nominative (cf. Tab. 1). Moreover, the adjective itself is obsolete since adjectives derived from a present participle almost never appear in Lux. In (2), the author even provides an expected vun-PP but then switches to a genitive, even though the PP-attribute seems to be the more authentic construction (two genitival attributes were used in the German original text). Yet it is unclear whether these examples are cases of hypercorrection or structural borrowing. Hypercorrection is the "overuse of an item considered to be socially or stylistically salient" (Hopper \& Traugott 2003: 137). This would mean that the prestigious use of the genitive in Standard German has an influence on the Luxembourgish language use. Associations of prestige and stigma are often found in adult language and in written styles (cf. Labov 1972; Disterheft 1990, quoted by Hopper \& Traugott 2003: 137f.). Since the majority of the Luxembourgish genitives described here are actually found in online text types (mainly in comments from rtl.lu and in texts from wikipedia.lu) and therefore part of written adult language, stylistic reasons might play a role in the use of the genitive.

Structural borrowing describes "the transfer of word-forms, morphemes, and even structural organization patterns from one language to another" (Matras 2011: 204). If this was the case for the Wikipedia-scenario at hand, then the Luxembourgish author

\footnotetext{
${ }^{10}$ German source text: So lässt sich ein bestanschließendes Ellipsoid (Referenzellipsoid) einer ganzen Region oder eines Kontinents ableiten (wikipedia.de).

${ }^{11}$ German source text: der mittlere Bahnradius seines Massezentrums (wikipedia.de).
} 
would simply adapt his sentence to the Standard German source by taking over certain structural aspects.

The difference between these two notions is that hypercorrection primarily relies on prestige and stigma while structural borrowing is in fact not connected to style. Additionally, hypercorrect borrowing strategies may lead to 'wrong' utterances. In such a case, speakers may not know the exact rules for certain forms and therefore develop new "cover-up" strategies (cf. Hopper \& Traugott 2003: 137). However the question whether these Luxembourgish genitives are considered 'right', 'wrong' or particularly prestigious requires another scientific approach and must remain unanswered at this point.

The so-called apostrophic genitive of the type grandma's hat does not appear in the corpus, except for one noun in a specific construction: Europas Zukunft (rtl.lu comments) 'Europe's future'. Maybe, Europas Zukunft has been reanalyzed as a compound since there is no obvious explanation for this special genitive use.

Example (4) shows that post-nominal attributes appear in different forms but (almost) never in the genitive. The word Méiglechkeet 'possibility' can take genitive attributes in German (die Möglichkeit des Wartens 'the possibility of waiting'), but Luxembourgish prefers a PP- or a VP-structure to succeed.

(4) d'Méiglechkeet, the possibility' vun-PP vun Wirtschaftsspionage ,of economic espionage' (rtl.lu comments)

$o p-\mathrm{PP}$ op eng gut zukunft ,of a better future' (rtl.lu comments)

ze-VP Subsiden ze kreien ,to receive funding' (forum)

fir...ze-VP fier matzeschwätzen ,to join in' (rtl.lu comments)

datt-VP datt mir eventuell all déi Coursen do kënnen ofhalen ,that we can maybe teach all these classes' (local council report)

Altogether, genitive attributes are very rare and belong either (a) to time adverbials or (b) to idioms, mostly derived from German, or (c) to a (hypercorrect?) use of German NP patterns. Attributes are in most cases introduced by a PP or underspecified NPs bearing no case information (non-oblique). 
- Genitive complements of verbs and adjectives

Adjectives and verbs can take genitive complements. In Luxembourgish, there are only few instances of genitive complements, mostly involving legal language as can be seen in examples (5) and (6).

(5) iwwerféieren, to convict'

$\begin{array}{lll}\text { wéinst-PP } & \begin{array}{l}\text { wéinst Doping iwwerfouert } \\ \text { because-of doping convicted }\end{array} & \mathrm{n}=7 \\ \text { vun-PP } & \begin{array}{l}\text { vum Doping iwwerfouert } \\ \text { of-the.DAT doping convicted }\end{array} & \mathrm{n}=1 \\ \text { Dat } & \text { dem Doping iwwerfouert } & \\ & \text { the.DAT doping convicted } & \mathrm{n}=1 \\ \text { Gen } & \text { des Dopings iwwerfouert } & \mathrm{n}=2 \\ & \text { the.GEN doping.GEN convicted } & \\ \text {, convicted of doping' } & \end{array}$

(6) sech schëlleg maachen ,to be guilty of'

$\begin{array}{ll}\text { an-PP } & \begin{array}{l}\text { sech an der selweschter Saach schëlleg gemaach } \\ \text {,the same affair' } \\ \text { (wikipedia.lu) } \\ \text { un-PP }\end{array} \quad \begin{array}{l}\text { sech un engem Massaker [...] schëlleg gemaach } \\ \text {, a massacre' } \\ \text { (radio news) } \\ \text { sech dem Amtsmissbrauch schëlleg gemacht } \\ \text { 'abuse of authority' } \\ \text { (rtl.lu comments) } \\ \text { sech enges Fehlverhalens schëlleg gemaach } \\ \text { Gen }\end{array} \quad \text { (rtl.lu comments) }\end{array}$

Seemingly, genitive complements do exist in Luxembourgish but always in coexistence with datives and PPs. However, the genitive use seems to be restricted to these two verb constructions in (5) and (6). ${ }^{12}$

Next to the aforementioned verbal complements, the corpus analysis also highlighted one adjective that frequently appears alongside genitives: (on-)wierdeg/-würdeg '(un-)worthy'. Again, the genitive competes with the dative.

\footnotetext{
${ }^{12}$ A prominent example cited in Lux. grammars (Schanen \& Zimmer 2012) and dictionaries (LWB) is the construction brauchen+pers.pro. ${ }^{\text {GEN }}$,to need someone'. The only two corresponding proofs come from older references: Ech brauch jo denger ${ }^{\mathrm{GEN}}$ net ,I don't need you' (De Rénert by Rodange, 1872). In recent texts, brauchen takes an accusative complement.
} 
(7) würdeg / wierdeg, worthy'

Dat

dësem Gemengerot würdeg

,worthy of this local council'

(local council report)

dem Chrëschtentum wierdeg

,worthy of Christianity'

(rtl.lu comments)

Gen

kenges Sportlers a kenges Staatschefs wierdeg ,worthy of no sportsman nor head of state'

(rtl.lu comments)

eng Pei di enges Letzebuergers würdeg as

, an income, that's worthy of a Luxembourger'

(rtl.lu comments)

When it comes to the genitive complement of verbs and adjectives, the genitive does occur on a small number of occasions and seems to be used in a pseudo-productive way ${ }^{13}$ (productive use in restricted contexts). Nevertheless, its use may be stylistically motivated - it mostly appears in the comments section online.

- Prepositions

There are hardly any prepositions governing genitives. Only in a few isolated instances were PPs encountered with a genitival NP. Again, the genitive noun

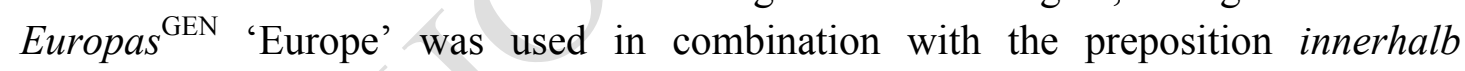
'within', where we again return to the question of whether this is in fact a real genitive or if this noun does have this unique lexicalized form.

Another example is the preposition trotz 'in spite of'. The corpus contains 4194 instances of trotz, out of which only two sentences show a genitive-NP with an overt genitive marker ( $s$-suffix on the article). ${ }^{14}$ One of the two examples is listed in (8).

(8) trotz senges mol méi mol manner souveränen in-spite his.GEN sometime more sometime less sovereign Optriedens an der Ëffentlechkeet presence.GEN in the public ,in spite of his more or less confident presence in public' (radio news)

\footnotetext{
${ }^{13}$ The term pseudo-productivity is introduced here as a first tentative categorization and describes a morpho-syntactic pattern that is used within limited contexts.

${ }^{14}$ The other instances show, in essence, dative NPs, dass-sentences, and case underspecified bare nouns.
} 
Furthermore, one single case shows the alleged postposition wegen governing a genitive NP (9).

(9) senges Amtes wegens

his.GEN position.GEN because.?GEN

,on his own motion'

(rtl.lu comments)

This case is very distinctive since it involves a unique postpositional use: firstly, it features the postposition wegen which does not appear in even the broadest Luxembourgish dictionary (LWB) and is presumably borrowed from German. Secondly, the overt genitive-s has misled the author of this phrase to place the same $s$ marker on the postposition itself.

The next example (10) illustrates the defectiveness of the genitive in the Luxembourgish case system. In 2012, an author on wikipedia.lu wrote an article on the Mercury project. In accordance with the German source text, he or she applied the exact word structure to Luxembourgish, turning the German original text auf Grund eines Strukturfehlers into the literal translation op Grond enges Strukturfeelers 'because of a structural defect'. Almost a year later, another user changed the genitive construction into a PP, featuring the preposition wéinst+dative 'because of'.

(10) a. op Grond enges Strukturfeelers on base a.GEN structural-defect.GEN

b. wéinst engem Strukturfeeler because-of a.DAT structural-defect (wikipedia.lu) ${ }^{15}$

However, the preposition wéinst 'because' bears a special feature. The qualitative corpus analysis shows that wéinst +genitive is in fact available for personal pronouns, although the quantitative approach in this case reveals that wéinst+dative is preferred: wéinst dir $^{\mathrm{DAT}}$ in 66 instances, wéinst denger ${ }^{\mathrm{GEN}}$ in 34 instances 'because of you'.

The amendment in (10) and the apparent preference structures show that - at least for prepositions - the genitive case is to be avoided. Under most circumstances, PPs or bare datives are applicable. Aside from the particular cases presented above, genitives are no longer governed by prepositions. They only appear in cases of strict German transliterations, in the construction wéinst + pers.pro. ${ }^{\text {GEN }}$ or sporadically with the noun Europas $^{\mathrm{GEN}}$. These single occurrences make it hard to draw the line between general variation in the system and hypercorrection, i.e. inaccurate use patterns.

\footnotetext{
${ }^{15}$ German Wikipedia text: Aber schon nach 59 Sekunden musste die Rakete auf Grund eines Strukturfehlers gesprengt werden (wikipedia.de).
} 
- Adverbials

Genitival adverbials can be simple units like mëttwochs, Wednesdays' or grammaticalized phrases like blannemännerchers ,blindly', gréisstendeels, largely' or kengesfalls, in no case'. Some adverbials can also appear under the form of a complex phrase: rouege Gewëssens, with a clear conscience', des Ëfteren 'frequently' or schwéieren Häerzens, with a heavy heart'.

It is undisputable that these forms are structural genitives. Nevertheless, diachrony (fossilized genitives) and synchrony (actual forms used today) are colliding at this point: most of the adverbials mentioned here are derived from historical genitives. Since the aim of this study is to identify the synchronic use patterns of genitives, these forms can be ignored. The lexicalized or idiomatized forms only prove that genitives are preserved in the Lux. language. The same holds for a range of adverbials in German (cf. Duden 2006: 982). A more precise analysis of the diachrony of the genitive case in Luxembourgish will be rewarding for future research purposes.

- Family names

In Luxembourgish, there are different ways of referring to individuals (as family members). One way is to mention their last name first (in a genitive form) and their first name afterwards: René (first name) Wohl (last name) $\Rightarrow>d e^{16}$ Wohls René (cf. Flores 2014). These family name constructions are decreasing gradually because they are mostly used by older generations and almost never appear in written language (only very few occurrences in the corpus). ${ }^{17}$

The inflection suffixes sometimes depend on the phonological properties of the last name. Names on -er for example are assimilated to -esch when a genitive-s is added to a female family member (-ers $>$-esch) (b). Short names that end on a consonant may take the weak genitive suffix $-e(n)^{18}(\mathrm{c})$. Alternatively, the last name may remain uninflected (d).

(11) a. Genitive (strong)

b. Genitive (assimilated)

c. Genitive (weak)

d. uninflected den Ewerts Vic

d'Beckesch Anne

den Trauschen Eric

d'Plein Mariette
'Vic Ewert'

'Anne Becker'

'Eric Trausch'

'Mariette Plein'

The semantic structure of this name construction is the following: The person bearing the last name $\mathrm{XY}$ is characterized as a member of the group $\mathrm{XY}$. The last name which is mentioned first represents the affiliation to the family $\mathrm{XY}$ and the first name determines the individual person in this group: de Rocken Ed (related group: the Rock

\footnotetext{
${ }^{16}$ In Luxembourgish, all forenames need to take an article. This sets the genitive- $s$ apart from the socalled Saxon genitive in German, where the genitival name itself is used as a determiner.

${ }^{17}$ The forms presented here result from my own survey conducted during the research for the LFA in 2012 (Atlas of Luxembourgish Family Names).

${ }^{18}$ The $n$ is dropped in certain phonological contexts (cf. Gilles 2006).
} 
family, individual: Ed) (cf. Bach 1952: 68-69). In some way, the last name takes the role of an attributive adjective. Ackermann (2014) provides evidence in Standard German for a formal restructuring of those two name components and argues that these forms bear a hybrid status between apposition and compound. This leads to the hypothesis that the genitive markers $\{-\mathrm{es}\}$ and $\{$-en $\}$ could also serve as linking elements in a compound structure (for more information about the grammatical structure of name combinations cf. Berchthold \& Dammel 2014; Cornelissen 2014).

This genitive construction is widely used by the older generation, making it a productive pattern to some extent. The boundaries of the construction rely on the fact that those genitives are rarely used by the younger speakers; that they mainly appear in oral speech; and that they only work in contexts where both the first and last name are combined.

- Partitives

Partitive pronouns are derived from Old-High German (OHG: 750-1050) genitive pronouns (cf. Strobel 2012: 410). Their function is a balance between partitivity and indefiniteness. The strong pronoun däers and the weak pronoun es derive from $\mathrm{OHG}$ $\ddot{e} s / i s$ (personal pronoun, $3^{\text {rd }}$ pers.sg.gen., $\mathrm{m}+\mathrm{n}$ ). In Luxembourgish, these inflectional features still hold for the contexts they can be used in. Däers/es can be used for uncountable nouns of masculine or neuter gender.

(12) Mir hunn däers/es genuch. $(+)$ we have PRO.PARTITIVE enough potential referents: Téi 'tea' (uncountable, m)

Gestreits 'wrangle' (uncountable, $\mathrm{n}$ ) as partitive-indefinite pronoun (no specification)

The pronoun pair där (strong form) and der (weak form) originate from $\mathrm{OHG}$ thëro/dëro (demonstrative pronoun, $3^{\text {rd }}$ pers.pl.gen.). The pronouns can either refer to uncountable feminine nouns or to plurals (without countability restrictions).
(13) Mir hunn där/der
genuch. $(+)$
we have PRO.PARTITIVE enough
potential referents: Mëllech 'milk' (uncountable, sg, f)
Äppel 'apples' (countable, pl, m)

These two forms, both in their strong and weak form, are frequently used in oral and written communication. They appear in all text genres and in different contexts.

When it comes to partitive pronouns that refer to countable nouns in the plural, they mostly denote indefiniteness rather than partitivity. This is, as it were, the plural equivalent of the indefinite pronoun eng 'one'. If one considers example (14), where the reference in (a) and (b) refers to the same countable noun, one can see that the only parameter that changes is number. Therefore, partitive pronouns can lose their partitive aspect and be strictly referential, indefinite in their value. 
(14) a. Et kann een der ginn als Enseignant.(ref.: Aufgaben, pl) it can one PRO.INDEF.PL give as teacher ,You may assign some as a teacher.' (ref.: homework, pl) (political interview)
b. Et kann een eng
ginn als Enseignant. (+) (ref.: Aufgab, sg)

it can one PRO.INDEF.SG give as teacher ,You may assign one as a teacher.'

(ref.: homework, sg)

(15) Si huet es vill a Si brauch es och vill. (ref.: Courage) she has PRO.PART much and she needs PRO.PART also much ,She has got a lot (of it) and she needs a lot (of it).' (ref.: courage) (political interview)

In sentence (15) the weak partitive pronoun es is an anaphoric reference to the uncountable masculine noun Courage 'courage'. The English translation shows that the pronoun es is somehow connected to the quantifier vill 'a lot'. This fact indicates that partitivity can also be linked to quantificational relations (cf. also the quantifier genuch 'enough' in the examples (12) and (13)).

As well as partitive pronouns, the Luxembourgish language makes use of a set of partitive articles similar to the strong forms of the partitive pronouns däers and där, bearing the same inflectional information: däers for uncountable singular nouns $(\mathrm{m}+\mathrm{n})$ and där as a partitive article for uncountable singular nouns (f) or plurals.

(16) Mir hunn nach där Äppel. (+)

,We still have (some of) these apples.'

(17) Mir hunn nach däers Fleesch. $(+)$

,We still have (some of) this meat.'

Partitive articles are often used in partitive attributes, preceded by quantifiers: 300 '000 Liter däers Ueleg '300'000 liters of this kind of oil', keent däers Gezei 'none of this kind of clothes', zevill däers Gudden 'too much of a good thing'. They also appear with iterative de-verbalized nouns: (genuch) däers Gespuers 'enough of the economizing' or (genuch) däers Gestreits 'enough of the wrangle'.

NPs containing a partitive article usually stand in the object position. Examples (18) and (19) show that partitive NPs (a) are fully interchangeable with a regular objectNP (accusative complement) (b).

(18) a. et leet een dann där klenger Steng dohinner

it lay one then ART.PART small.GEN stones there

(local council report)

b. et leet een dann (déi) kleng Steng dohinner $(+)$

it lay one then (these) small stones there

'one places (these) little stones there, then' 

(19) a. gidd emol där klenger Rido's Réngelcher ${ }^{19}$ kafen go sometime ART.PART small.GEN curtain-rings.DIM buy (rtl.lu comments)
b. gidd emol (déi) kleng Riddosréngelcher kafen (+)
go sometime (these) small curtain-rings.DIM buy ,go and buy (these) small curtain rings'

The semantic contrast reveals that the sentences in (a) refer to a certain set of stones or curtain rings, whereas (b) stands for the mentioned item in general without specifying which. Although both sentences contain the same core information, the object in (a) is more clearly specified because of the partitive construction. Among the small stones or curtain rings, only a certain set of these items is meant (only one specific kind).

Moreover, the constructions in (a) and (b) are formally and functionally different: aside from the different articles, the partitive NP in (a) features the inflectional suffix $\{-e r\}$ on the adjective kleng, whereas (b) has zero marking on the adjective. This reverts to the matter of the genitive marking on adjectives addressed in chapter 3 (cf. also table 1). A closer look at partitive constructions reveals the following inflectional suffixes for adjectives. ${ }^{20}$

\begin{tabular}{llll}
\hline & \multicolumn{2}{c}{ Partitive } \\
\hline M.: & $\{+\mathrm{en}\}$ & däers gudd-en Hunneg & 'good honey' \\
N.: & $\{+\mathrm{en}\}$ & däers deier-en Holz & 'expensive wood' \\
F.: & $\{+\mathrm{er}\}$ & där gudd-er Mëllech & 'good milk' \\
Pl.: & $\{+\mathrm{er}\}$ & där kleng-er Betrib-er & 'small companies' \\
\hline
\end{tabular}
Tab. 3: partitive marking on the NP-level

The partitive structures found in the Luxembourgish language are polyfunctional: They can simply be referential (and indefinite in their value), or may denote partitivity. In addition, Schanen and Zimmer $(2012: 99,154)$ claim that nominalized adjectives in the plural (without a determiner) take the partitive suffix -er: domm 'dumb' => en Dommen 'a dumb person' => Ø Dommer 'dumb people' (as opposed to: déi Domm-Ø 'the dumb people'). The partitivity issue in Luxembourgish is definitely worthy of further research in the future (cf. Döhmer: in preparation). ${ }^{21}$

How can the Luxembourgish partitive be classified? In theory, there are different theoretical approaches: From a diachronic point of view, it may still remain a

\footnotetext{
${ }^{19}$ The compound Riddosréngelcher, small curtain rings' has been orthographically reanalyzed to Rido's Réngelcher. This seems to be very interesting since there is no apostrophic genitive in Luxembourgish.

${ }^{20}$ Nevertheless, it remains unclear whether these suffixes are identical to genitive suffixes. The corpus does not contain enough adjectives in different genitive constructions to draw parallels here. This shows that partitives are very common in the Luxembourgish language.

${ }^{21}$ Cf. Glaser $(1992,2006)$ and Strobel (2012) for partitive structures in different German varieties.
} 
preserved subcategory of the genitive or it may represent an "independent partitive genitive" 22 with different aspects of indefiniteness and quantification (cf. Seržant $2014^{\mathrm{a}}, 2014^{\mathrm{b}}$ ).

The idea of a further expansion of the former partitive genitive suits the current topic, because in the Luxembourgish language these partitive structures developed into a broader, multi-faceted system of partitive pronouns, articles, and indefinite plurals. ${ }^{23}$ Therefore it should not be seen as a subcategory of the genitive but rather a further stage of the partitive, resulting in an independent partitive system.

\section{Summary}

The data presented in this study shows that some genitives still exist on a productive basis, predominantly on the level of specific adjectival or verbal constructions and partitives. Genitive structures are mostly found in idiomatic phrases with more or less restrictive use patterns, displaying a high degree of lexicalization. In some instances, genitive complements occur with legal terminology or other specific constructions. This restricted use can be described as a case of pseudo-productivity since the genitives appear in various contexts but with a very limited set of verbs or adjectives. As regards genitival attributes and prepositions in Luxembourgish, one can claim that they are infrequent and mostly unproductive. Several instances from the corpus turned out to be literal translations or lexicalized structures, resulting in hypercorrect or fossilized genitives. The synthetic genitive for family names is a productive pattern but its use is gradually decreasing.

According to the text types, genitives were mostly encountered in the comments sections on the web. In the spoken data (family interviews), only partitive structures were found. Altogether these partitives play a major role in Luxembourgish syntax and semantics. Yet one must thoroughly investigate whether they represent a subcategory of the genitive or a system of their own. There is no doubt that these structures are derived from a former genitive but they have evolved into a wider, polyfunctional system, gaining more and more independence from the genitive system (cf. Döhmer: in preparation).

\footnotetext{
${ }^{22}$ The notion of the independent partitive genitive (IPG) was developed by Seržant $\left(2014^{\mathrm{a}}, 2014^{\mathrm{b}}\right)$ in his research on partitive structures in Lithuanian and North Russian. The independency feature is based on the fact that the genitive is not directly governed by a head.

${ }^{23}$ One might wonder if the expansion of the Lux. partitive system is linked to language contact with French (which has a large partitive system as well). Since the different languages in Luxembourg are clearly divided into different domains, there is no intense contact between Luxembourgish and French. Another issue is the decreasing prestige of the French language in the Luxembourgish community. This decrease is for instance structurally reflected in phonological changes, i.e. the change from a more French-oriented pronunciation of Lux. consonants towards a more German-oriented articulation, as shown by Conrad (2015). There is at least no clear evidence for a language contact hypothesis in the partitivity matter.
} 
The present study provides corpus-based evidence that the use of the genitive (i.e. genitive complements) is somewhat limited, whereas partitive structures (i.e. former genitives) are a very common phenomenon. The current use of the genitive as a verbal or adjectival complement might be explained by the expansion of the Luxembourgish language into the written domain leading to a greater preference for genitives due to stylistic reasons. Especially the frequency of genitives in online genres shows new dynamics in Luxembourgish written communication, enhanced by technical and cultural progress. The growing importance of digital communication is a challenge for the Luxembourgish community (cf. Belling 2015: 295) and prepares the ground for new styles and registers.

In conclusion, changes in the language situation result in dynamics at a structural level. The language system needs to allow for variation in order to allow structural change or, as Seiler and Salzmann (2010: 81) put it, "intra-speaker variation is normal and variation is rooted in the internal structure of grammar itself".

This descriptive overview of the current use of genitives in the Luxembourgish language shows the obvious need for further research in the fields of Lux. language structure and grammatical categories, be it comparative, structural or diachronic.

\section{Bibliography}

Ackermann, Tanja (2014): Vom Syntagma zum Kompositum? Der grammatische Status komplexer Personennamen im Deutschen. In: Friedhelm Debus, Rita Heuser, \& Damaris Nübling (eds.), Linguistik der Familiennamen, 11-38. Hildesheim; Zürich; New York: Georg Olms Verlag.

Ágel, Vilmos (2000): Syntax des Neuhochdeutschen bis zur Mitte des 20. Jahrhunderts. In: Werner Besch, Anne Betten, Oskar Reichmann, \& Stefan Sonderegger (eds.), Sprachgeschichte. Ein Handbuch zur Geschichte der deutschen Sprache und ihrer Erforschung, 1855-1903. Berlin; New York: De Gruyter.

Androutsopoulos, Jannis K. (2007): Neue Medien - neue Schriftlichkeit? Mitteilungen des Germanistenverbandes, 54(1), 72-97. Available at: http://jannisandroutsopoulos.files.wordpress.com/2009/12/androutsopoulos_2007-neuemedien-neue-schriftlichkeit.pdf [Accessed January 5, 2015].

Bach, Adolf (1952): Die Verbindung von Ruf- und Familiennamen in den deutschen, insbesondere den rheinischen Mundarten. Rheinische Vierteljahrsblätter, 17, 66-88.

Belling, Luc (2015): Mediale und sprachliche Möglichkeitsräume in digitaler Schriftlichkeit Eine Studie zu Facebook-Pinnwänden in Luxemburg. PhD thesis. University of Luxembourg.

Berchthold, Simone \& Dammel, Antje (2014): Kombinatorik von Artikel, Ruf- und Familiennamen in Varietäten des Deutschen. In: Friedhelm Debus, Rita Heuser, \& 
Damaris Nübling (eds.), Linguistik der Familiennamen, 249-280. Hildesheim; Zürich; New York: Georg Olms Verlag.

Bruch, Robert (1955): Précis populaire de Grammaire Luxembourgeoise - Luxemburger Grammatik in volkstümlichem Abriss, Luxembourg: Editions de la Section de Linguistique de l'Institut gr.-d.

Burger, Harald (2007): Phraseologie. Eine Einführung am Beispiel des Deutschen. $3^{\text {rd }}$ edition. Berlin: E. Schmidt.

Conrad, François (2015): Sprachkontaktinduzierte Variation im luxemburgischen Konsonantismus. PhD thesis. University of Luxembourg.

Cornelissen, Georg (2014): Genitivierungen bei vorangestellten Familiennamen im Kleverländischen. Rezente und diachrone Befunde. In: Friedhelm Debus, Rita Heuser, \& Damaris Nübling (eds.), Linguistik der Familiennamen, 281-296. Hildesheim; Zürich; New York: Georg Olms Verlag.

Disterheft, Dorothy (1990): The role of adaptive rules in language change. Diachronia, 7, 181-198.

Döhmer, Caroline (in preparation): Aspekte der luxemburgischen Syntax. PhD thesis. University of Luxembourg.

Duden (2006): Duden - Die Grammatik. $7^{\text {th }}$ edition, Dudenredaktion (ed.), Mannheim; Leipzig; Wien; Zürich: Dudenverlag.

Fillmore, Charles, Paul Kay, and Catherine O'Connor (1988): Regularity and Idiomaticity in Grammatical Constructions: The Case of let alone. Language, 64, 501-538.

Flores Flores, Amaru W. (2014): Zur Grammatik der Familiennamen im Luxemburgischen. Kombinatorik mit Rufnamen, Bildung des Plurals und Movierung. In: Friedhelm Debus, Rita Heuser, \& Damaris Nübling (eds.), Linguistik der Familiennamen, 297-319. Hildesheim; Zürich; New York: Georg Olms Verlag.

Gilles, Peter \& Moulin, Claudine (2003): Luxembourgish. In: Ana Deumert \& Wim Vandenbussche (eds.), Germanic Standardizations. Past to Present, 303-330. Amsterdam; Philadelphia: Benjamins.

Gilles, Peter (2006): Phonologie der $n$-Tilgung im Moselfränkischen ('Eifler Regel'). Ein Beitrag zur europäischen Prosodieforschung. In: Claudine Moulin \& Damaris Nübling (eds.), Perspektiven einer linguistischen Luxemburgistik, 29-68. Heidelberg: Winter.

Gilles, Peter (2011): Mündlichkeit und Schriftlichkeit in der luxemburgischen Sprachengemeinschaft. In: Georg Mein \& Heinz Sieburg (eds.), Medien des Wissens. Interdisziplinäre Aspekte von Medialität, 43-64.

Glaser, Elvira (1992): Umbau partitiver Strukturen in der Geschichte des Deutschen. Sprachwissenschaft, 17(2), 113-132.

Glaser, Elvira (2006): Zur Syntax des Lëtzebuergeschen: Skizze und Forschungsprogramm. In: Claudine Moulin \& Damaris Nübling (eds.), Perspektiven einer linguistischen Luxemburgistik, 227-246. Heidelberg: Winter. 
Hoffmann, Jean-Paul (1996): Lëtzebuergesch and its Competitors: Language Contact in Luxembourg Today. In: Gerald Newton (ed.), Luxembourg and Lëtzebuergesch. Language and Communication at the Crossroads of Europe, 97-108. Oxford: Oxford University Press.

Hopper, Paul J. \& Traugott, Elizabeth Closs (2003): Grammaticalization. $2^{\text {nd }}$ edition, New York: Cambridge University Press.

Kloss, Heinz (1978): Die Entwicklung neuer germanischer Kultursprachen seit 1800. Schwann, Düsseldorf.

Labov, William (1972): Sociolinguistic patterns, Philadelphia: University of Pensylvania Press.

LWB (1950): Luxemburger Wörterbuch (5 volumes). Wörterbuchkommission (ed.), Luxembourg: P. Linden. Available at: http://infolux.uni.lu/worterbucher/ [Accessed January 5,2015$]$.

Matras, Yaron (2011): Universals of structural borrowing. In: Peter Siemund (ed.), Linguistic universals and language variation, 204-233. Berlin: Mouton.

Nübling, Damaris (2008): Historische Sprachwissenschaft des Deutschen. Eine Einführung in die Prinzipien des Sprachwandels. $2^{\text {nd }}$ edition, Tübingen: Narr (with Antje Dammel, Janet Duke, Renata Szczepaniak).

Rodange, Michel (1872 [2008]): Renert. De Fuuss am Frack an a Maansgréisst. Romain Hilgert (ed.), Luxembourg: Binsfeld.

Russ, Charles (1996): Lëtzebuergesch - a linguistic description. In: Gerald Newton (ed.), Luxembourg and Lëtzebuergesch. Language and communication at the crossroads of Europe, 67-95. Oxford: Clarendon Press.

Schanen, François \& Zimmer, Jacqui (2012): 1,2,3 Lëtzebuergesch Grammaire Luxembourgeoise, Esch-sur-Alzette: Editions Schortgen.

Scott, Alan K. (2011): Everyday Language in the Spotlight: The Decline of the Genitive Case. German as a Foreign Language, 12, 53-70.

Scott, Alan K. (2014): The Genitive Case in Dutch and German: A Study of Morphosyntactic Change in Codified Languages. Leiden \& Boston: Brill.

Seiler, Guido \& Salzmann, Martin (2010): Variation as the exception or the rule? Swiss relatives revisited. Sprachwissenschaft, 35, 79-117.

Seržant, Ilja A. (2014 ): The Independent Partitive Genitive in Lithuanian. In: Axel Holvoet \& Nicole Nau (eds.), Grammatical Relations and their Non-Canonical Encoding in Baltic, 257-99. Valency, Argument Realization and Grammatical Relations in Baltic. Amsterdam: John Benjamins Publishing Company.

Seržant, Ilja A. (2014 $)$ : The Independent Partitive Genitive in North Russian. In: Ilja A. Seržant \& Björn Wiemer (eds.), Contemporary Approaches to Dialectology: The area of North, Northwest Russian and Belarusian vernaculars, Slavica Bergensia 13, 270-329. 
Bergen: John Grieg AS. Available at: http://www.unikonstanz.de/serzants/Serzant_IPG_NorthRussian.pdf [Accessed January 5, 2015].

Strobel, Thomas (2012): On the areal and syntactic distribution of indefinite-partitive pronouns in German: Methodological advances and empirical results within the project Syntax of Hessian Dialects (SyHD). In: Álvarez Pérez, Xosé Afonso, Ernestina Carrilho, \& Catarina Magro (eds.), Proceedings of the International Symposium on Limits and Areas in Dialectology (LimiAr), 405-430. Centro de Linguística da Universidade de Lisboa. Available at: http://limiar.clul.ul.pt/proceedings/workshop/26_strobel.pdf [Accessed January 5, 2015].

Szczepaniak, Renata (2011): Grammatikalisierung im Deutschen. Eine Einführung. $2^{\text {nd }}$ edition, Tübingen: Narr.

Szczepaniak, Renata (2014): Sprachwandel und sprachliche Unsicherheit. Der formale und funktionale Wandel des Genitivs seit dem Frühneuhochdeutschen. In: Albrecht Plewina \& Andreas Witt (eds.), Sprachverfall? Dynamik - Wandel - Variation, 33-50. Berlin; New York: De Gruyter.

Willems, Klaas (1997): Kasus, grammatische Bedeutung und kognitive Linguistik. Ein Beitrag zur allgemeinen Sprachwissenschaft, Tübingen: Günter Narr Verlag.

Zimmer, Christian (this volume): On the motivation of genitive-s-omission in Contemporary German.

Internet sources:

http://www.wikipedia.lu; http://www.wikipedia.de

http://www.rtl.lu 